\title{
ОБҐРУНТУВАННЯ ДОЦІЛЬНОСТІ СТВОРЕННЯ ОПЕРАТОРА РУХУ ЕЛЕКТРОННИХ ВІДХОДІВ ВІД КОРИСТУВАЧА ДО ПЕРЕРОБНОГО ПІДПРИЄМСТВА ДЛЯ ЗАПОБІГАННЯ РОЗВИТКУ НЕФОРМАЛЬНОГО СЕКТОРУ ПОВОДЖЕННЯ З ВІДХОДАМИ В УКРАЇНІ
}

\author{
Шевченко Тетяна Іванівна. \\ кандидат економічних наук, доцент \\ Сумський національний аграрний університет (м.Суми, Україна) \\ ORCID: 0000-0002-3213-819X \\ tanya.shevchenko@snau.edu.ua
}

Гончарова Наталія Іванівна Глухівський агротехнічний інститут Сумського національного аграрного університету (м. Глухів, Україна) nhoncharova1979@ukr.net

Мельник Юлія Юріївна бакалавр Сумський національний аграрний університет (м.Суми, Україна) apletre@ukr.net

У статті обгрунтовано доцільність створення локального оператора руху відпрацьованого електричного та електронного обладнання (ВEЕО) при спеціалізованому переробному підприємстві для запобігання розвитку неформального сектору поводження з відходами в Україні. Запропоновано систему реверсу ВEЕО, за десятьма категоріями, від користувача до переробного підприємства на основі електронної обробки запитів користувачів на збирання цих відходів та створення відповідної інформаційної бази. Інформаційна база запитів з відповідними інтерактивними опline-картами дозволить мінімізувати транспортні витрати та зменшити СО2 за рахунок використання наявного потенціалу маршрутів транспортних засобів місцевих служб доставки для роздільного збирання електронних відходів у місті, замість введення цільового транспорту для збирання відходів.

Ключові слова: побутові відходи, електронні відходи, відходи електричного та електронного обладнання, неформальний сектор, роздільне збирання.

DOI: https://doi.org/10.32845/bsnau.2019.3.5

Актуальність теми дослідження. Щорічно у світі утворюється близько 50 млн т електронних відходів, більша частина яких накопичується у навколишньому середовищі [20]. Обсяги їх утворення зростають на 3-5\% на рік [21], що обумовлено зростанням попиту на електронне обладнання та невеликим терміном їх корисного використання. У глобальному масштабі за 2016 рік лише 8,9 млн т електронних відходів були офіційно зібрані та утилізовані (від утворених 44,7 млн т), що відповідає 20\%, а решта - 80\% (35,8 млн т) - документально не оформлені [8].

Не дивлячись на те, що електронні відходи становлять лише 1-3\% від твердих побутових, вони є найбільш шкідливими серед відходів споживання, оскільки містять токсичні речовини - свинець, ртуть, хром, кадмій ін. Крім цього, відходи електричних та електронних виробів містять дорогоцінні метали, включаючи золото, срібло, мідь, платину та паладій, а також інші матеріали, такі як залізо, алюміній, пластмаси, які можуть бути повторно використані. Недосконалість існуючого законодавства у сфері поводження з цими відходами у країнах світу призводить до розвитку неформального сектору переробки [9,13,15], коли відбувається вилучення найбільш ліквідних частин/цінних компонентів, а решта викидається, завдаючи шкоду навколишньому середовищу і здоров'ю людей.

За результатами оцінки ефективності поточних програм збирання електронних відходів, які діють у країнах, що розвиваються, наразі існує два основних виклики - розвиток неформального сектору та накопичення відпрацьованих ви-

робів вдома. Навіть у розвинутих країнах, де сформовано достатню та зручну інфраструктуру, тенденція «накопичення вдома» все ще спостерігається і виникає питання чому? Факторів, що впливають на поведінку користувача багато, але ми виділяємо основний - користувач не сприймає відпрацьовані електричні та електронні вироби як відходи, а як використані вироби, що мають залишкову вартість. Ось чому у країнах, що розвиваються, зростає неформальний сектор збирання, а деякі типи відпрацьованих виробів населення накопичує вдома. У розвинутих країнах споживачі також накопичують вдома відпрацьовані вироби, можливо чекаючи економічних стимулів, оскільки індустрія рециклінгу є високоприбутковою, і люди не сприймають їх як відходи, а як сировину для переробних підприємств [19]. Отже, для належного та вчасного повернення користувачем відпрацьованого побутового обладнання необхідно формувати зручну та достатню інфраструктуру, а також створювати економічні стимули.

Аналіз останніх досліджень. Нещодавні публікацій за тематикою поводження з електронними відходами в Україні О.Р. Губанової [3], Г.П. Виговської [2], Н.М. Андрєєвої [1], Н.І. Хумарової [4], Н.Й. Шуптар [7], Конджебаш А.П. [4] мають достатньо широкий спектр питань, що обумовлено міждисциплінарним характером проблематики. Аналіз цих праць свідчить про актуальність досліджень у тому числі у напряму інфраструктурного забезпечення роздільного збирання відходів електричного та електронного обладнання (BEEO) у відповідності до норм та стандартів ЄС. Для регулювання процесів поводження з цими відходами у ЄС діє відповідна директива, яка містить заходи щодо запобігання або зменшення 
несприятливого впливу процесів поводження з цими відходами на довкілля, а також визначає загальні вимоги щодо збирання та встановлює мінімальні щорічні норми збирання [12]. Для досягнення встановлених норм країни-члени повинні формувати відповідну інфраструктуру збирання відходів, що дозволить кінцевим користувачам повернути відпрацьовані електронні вироби принаймні безкоштовно. Практика розподілу фізичної та фінансової відповідальності за збирання та утилізацію електронних відходів між виробниками та дистриб'юторами у країнах-членах ЄС більш детально досліджена у працях О.Р. Губанової [3] та Н.Й. Шуптар [7]. Вчені підкреслюють, що серед усіх учасників ланцюжку збереження цінності матеріалу у економічній системі якомога довше, роль споживача є достатньо вагомою, оскільки він є одночасно покупцем та користувачем виробу, а також власником відпрацьованого виробу, якого потрібно позбутися належним чи- ном. Для належного повернення електронних відходів необхідно формувати зручну систему збирання [6, 3] і створювати економічні стимули [5].

Мета цього дослідження - обґрунтувати доцільність створення локального оператора руху ВЕЕО від користувача до спеціалізованого переробного підприємства для запобігання розвитку неформального сектору поводження з цими відходами в Україні. Об'єктом дослідження є система роздільного збирання ВЕЕО. Предмет дослідження - технології збирання електронних відходів.

Результати дослідження. У глобальному масштабі за 2016 рік лише 8,9 млн т електронних відходів були офіційно зібрані та утилізовані від утворених 44,7 млн т, що відповідає 20\%, а решта - 80\% (35,8 млн т) - документально не оформлені $[8,22]$. Обсяги утворення електронних відходів за 2014-2021 рр., у тому числі прогнозовані значення, представлені на рис. 1.

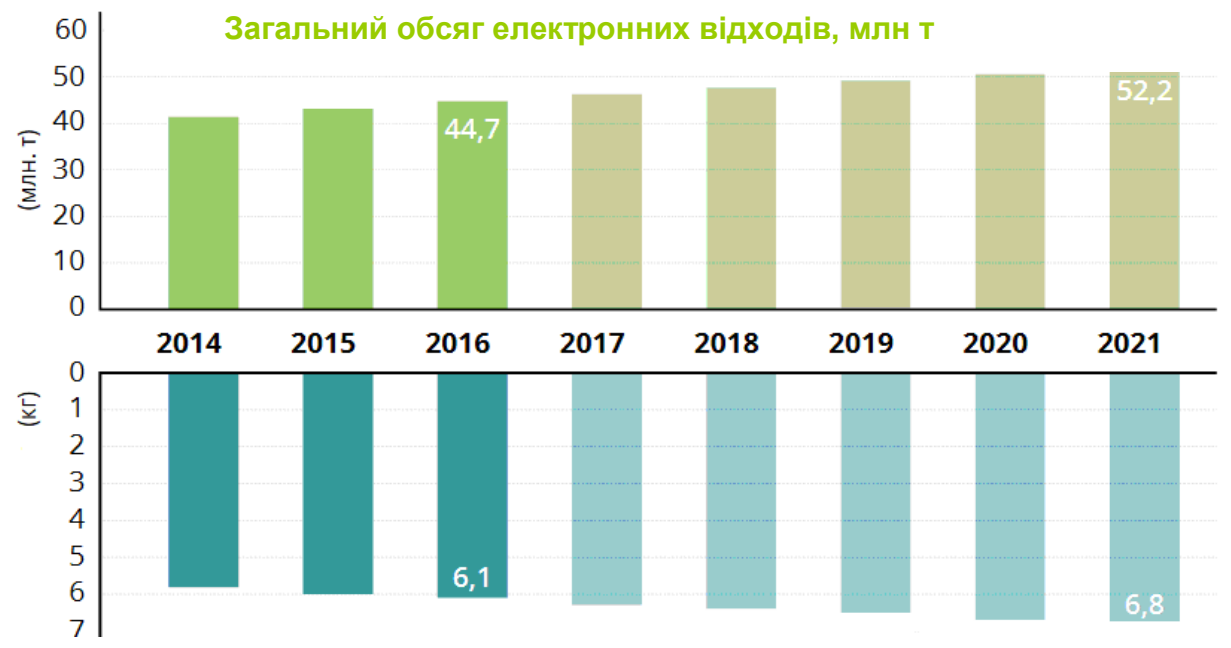

Обсяг електронних відходів на людину, кг

Рисунок 1 - Обсяги утворення електронних відходів у світі за 2014-2021 pp. [8]

Очікується, що обсяг електронних відходів збільшиться до 52,2 млн т у 2021 р, демонструючи зростання на 34\% на рік. У той же час різні категорії виробів демонструють різні темпи річного зростання. Найбільші темпи зростання обсягів очікуються для відпрацьованого терморегулюючого обладнання, а також малогабаритного і крупногабаритного обладнання (рис. 2).

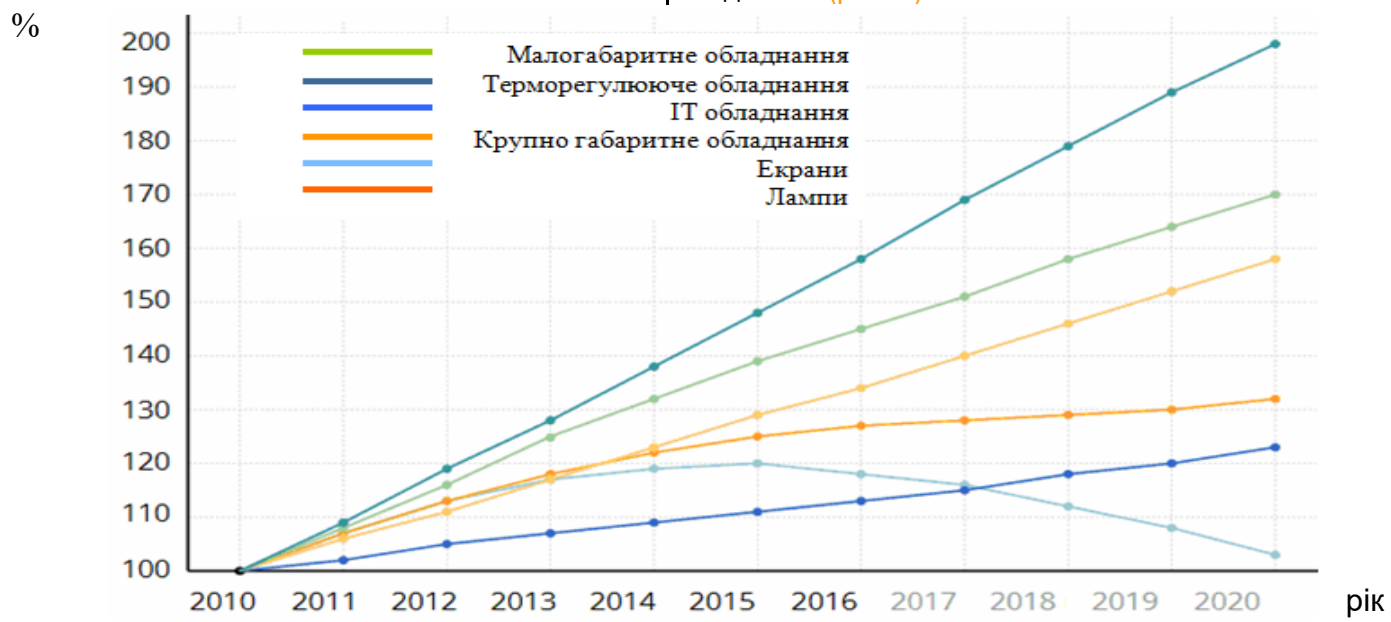

Рисунок 2 - Темпи зростання електронних відходів за категоріями обладнання у світі, 2010-2020 pp. [ $\varepsilon_{\text {J }}$

За показниками 2016 року на Азію припадає найбільший обсяг електронних відходів - 18,2 млн т або 4,2 кг на душу населення, на Європу - 12,3 млн т (16,6 кг/люд), Північну та Південну Америки - 11,3 млн т (11,6 кг/люд), Африку 2,2 млн т (1,9 кг/люд), Океанію - 0,7 млн т (17,3 кг/люд). Отже, 
в Океанії найбільший обсяг утворення електронних відходів в розрахунку на людину, а частка в офіційному оформлені обсягів їх збирання та переробки склала лише 6\%. Найбільша норма збирання електронних відходів станом на 2016 р. досягнута у Європі - 35\%, далі йдуть Північна та Південна Америки - $17 \%$, Азія - 15\% та Океанія - $6 \%$.

Недосконалість існуючого законодавства у сфрері поводження з електронними відходами у країнах світу сприяє розвитку неформального сектора їх переробки. Неформальний сектор поводження з електронними відходами часто розглядається як недоступний для регулювання та управління, коли неконтрольовано відбувається вилучення найбільш ліквідних частин/цінних компонентів, а решта викидається, завдаючи шкоду навколишньому середовищу і здоров'ю людей.

У кожній країні розвиток неформального сектору має свої особливості. Наприклад, у Китаї менталітет жителів «відходи як цінність» та недосконалість законодавчих норм сприяють розвитку неформального сектору переробки. Згідно досліджень Лу та ін. [14], 94\% домашніх господарств позбуваються електронних відходів через неформальні канали збирання. У деяких провінціях їх збирання відбувається на велосипедах та візках «від дверей до дверей», коли відпрацьовані електронні прилади купуються у користувачів, а потім перепродаються для переробки [21,14]. Ціни на відпрацьовані вироби, що пропонує неформальний сектор у Китаї станом на 2014 р, представлені на діаграмі (рис. 3). В Індії неформальний сектор також є звичайною практикою, де 95\% електронних відходів поглинається цим сектором [9]. Споживачеві платять за відпрацьоване/ застаріле побутове обладнання, що є економічним стимулом позбуватися непотрібних речей саме через неформальні канали збирання. Значну шкоду навколишньому середовищу і здоров'ю людей завдає «переробка» електронних відходів у Нігерії, де відсутні елементарні законодавчі норми щодо поводження з ними. Відпрацьовані вироби переробляються з використанням грубих методів, а небажані компоненти викидаються в місцеві звалища або поверхневі водойми $[15,16]$.

Слід підкреслити, що у поєднанні з функціонуванням формальної системи збирання електронних відходів неформальна система може залишатися потужною [17 11]. За результатами досліджень [11, 23], відсутність стимулів $€$ основною причиною, що спонукає домогосподарства повертати електронні відходи через неформальний сектор, хоча більше половини респондентів обізнані про важливість екологічно безпечної утилізації.

У Румунії, як нещодавньої країни-члена ЄС, нефрормальна система залишається працездатною, не дивлячись на те, що створено офріційну системи збору електронних відходів із зручними каналами збору, надаються знижки на нове обладнання при поверненні відпрацьованого. Згідно з опитуванням, проведеним в Румунії, 42,29\% респондентів відповіли, що вони позбавляються від старої електрики та електроніки використовуючи муніципальну системи поводження, в той час як $29,25 \%$ респондентів збувають старе обладнання через неформальну систему збирання [10].

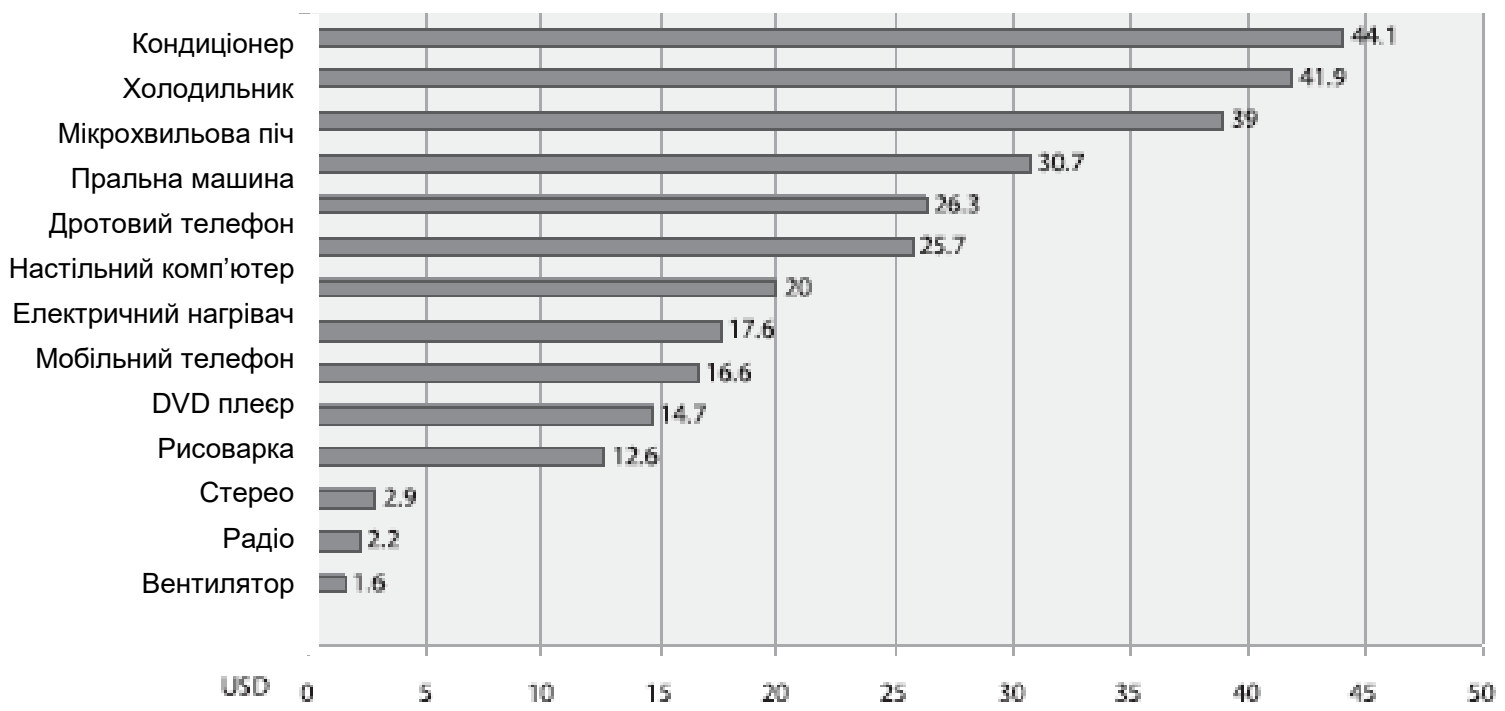

Рисунок 3 - Ціни на відпрацьовані вироби, що пропонує неформальний сектор збирання у Китаї станом на 2014 p [11]

В Україні також має місце збирання електронних відходів через неформальний сектор, коли споживачі здають деякі категорії побутового обладнання, наприклад, ремонтним підприємствам за певну плату. Далі відбувається вилучення найбільш цінних частин/деталей обладнання, а решта вивозиться на муніципальні звалища, забруднюючи навколишнє середовище. Деякі спроби вирішення проблеми збирання BEEO спостерігаються з боку громадських організацій у вигляді проведення відповідних акції, а також окремі зусилля робляться торгівельними підприємствами, які приймають деякі типи відпрацьованого обладнання, надаючи певну знижку при покупці нового виробу. На жаль, більша частина електронних відходів в Україні потрапляє на полігони та звалища, а з ними щорічно - близько 500 кг ртуті, 160 кг кадмію, 260 т марганцевих сполук, 250 т натрієвих хлоридів.

Для стримування розвитку неформального сектору поводження з електронними відходами у містах України, вважаємо за доцільне створення локального оператора руху BEEO при спеціалізованому переробному підприємстві, призначення якого - обробка запитів споживачів на збирання BEEO та створення інформаційної бази заявок із відповідними інтерактивними online-картами для спрощення процесу 
їх подальшого збирання та транспортування.

За результатами попередніх досліджень [6] встановлено, що в містах існує наявний невикористаний потенціал для перевезення електронних відходів, який мають місцеві служби доставки. Транспортні засоби служб доставки можуть розглядатися як потенційні мобільні приймальні пункти, які без суттєвого відхилення від запланованого маршруту могли б забирати у споживача відпрацьоване/ застаріле побутове обладнання. Залучення служб доставки міста до збирання BEEO є економічно та екологічно доцільним, оскільки це дозволяє мінімізувати витрати на перевезення цих відходів, а також уникнути викидів СО2 та інших забруднюючих речовин, обумовлених створенням цільової системи збирання електронних відходів.

На нашу думку, вищезазначені інтерактивні onlineкарти запитів користувачів створюють передумови для залучення транспортних засобів будь-яких місцевих служб доставки до процесу збирання BEEO. Окрім обробки запитів, локальний оператор руху BEEO буде залучати місцеві служби доставки до процесу їх збирання у місті на умовах вигідних для усіх залучених стейкхолдерів.

Умовна інтерактивна online-карта запитів користувачів на збирання електронних відходів у м. Суми та умовний маршрут транспортного засобу служби доставки представлені на рис. 4. За цією схемою перевізник забирає електронні відходи у споживача за попередньою заявкою та здійснює їх перевезення до спеціалізованого переробного підприємства суттєво не відхиляючись від запланованого маршруту. Заявка на збирання має містити інформацію щодо категорії відпрацьованого побутового обладнання та часу обслуговування, зручного для споживача. Запропонований підхід - обслуговування за запитом користувача, дозволяє здійснити збирання старих виробів з мінімальними трансакційними витратами для споживача, що мотивує його позбавлятися відпрацьованих виробів належним чином. Крім цього, для якомога повнішого збирання, доцільно створювати економічні стимули для користувача, щоб компенсувати частини залишкової вартості відпрацьованого обладнання за категоріями.

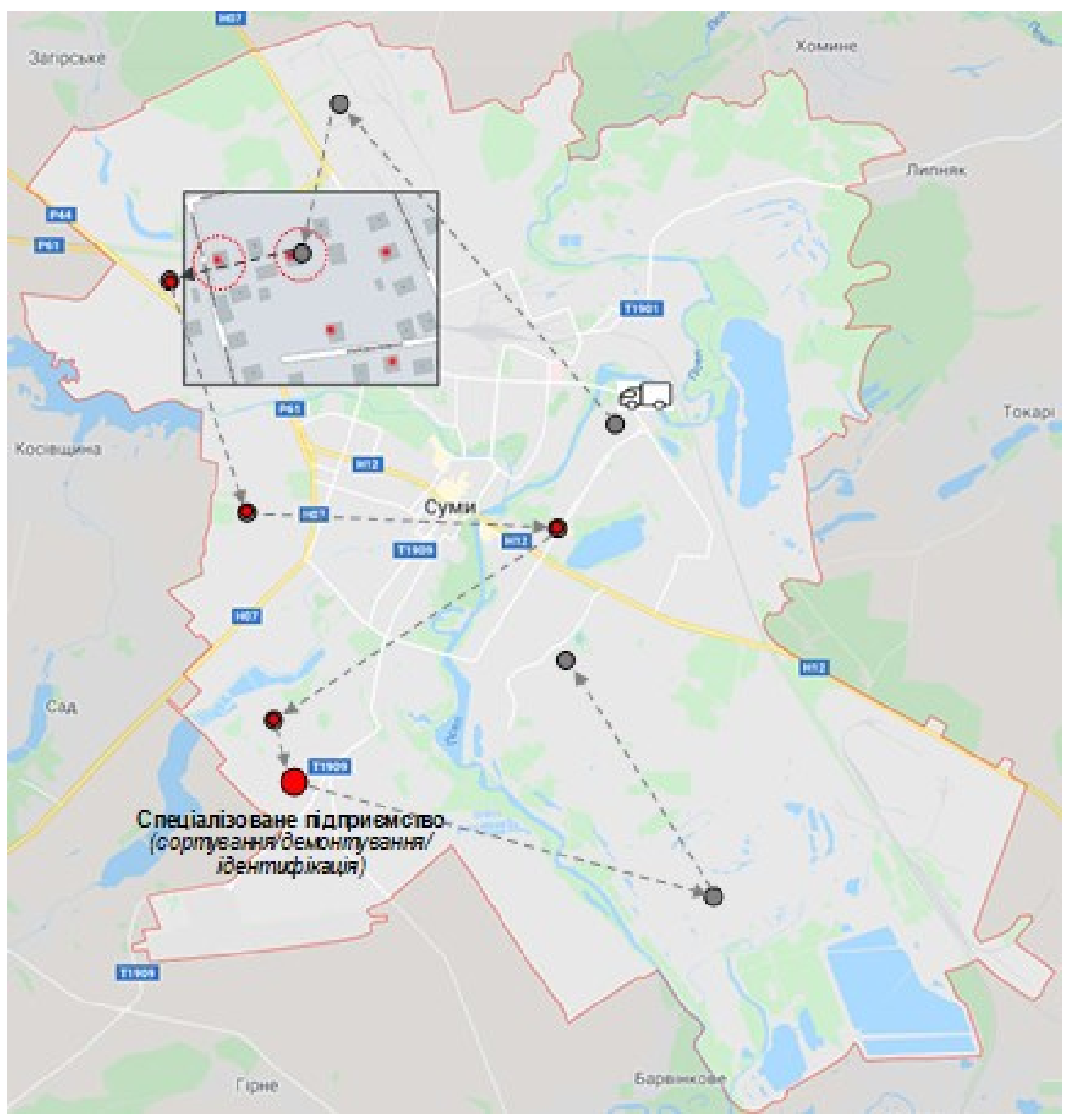

Рисунок 4 - Умовна інтерактивна online-карта запитів користувачів на збирання електронних відходів у м. Суми та умовний маршрут транспортного засобу служби доставки

Схема забезпечення зворотного руху ВEEО на основі обробки заявок користувачів та залучення підприємств, що надають послуги доставки, представлена на рис. 5.

За цією схемою ключова роль у системі забезпечення реверсу відпрацьованих/ застарілих виробів належить локальному оператору руху BEEO при спеціалізованому переробному підприємстві, яке створює ціннісну пропозицію для усіх користувачів електричного та електронного обладнання 
(ЕЕО). Послуга збирання електронних відходів задовольняе потребу споживача у позбавленні від зайвих непотрібних речей, які накопичуються вдома, з найменшими трансакційними витратами для нього (час, грошові кошти, зусилля). 3 метою якомога повнішого збирання цих відходів оператор взаємодіє зі споживачем через служби доставки при торгівельних підприємствах («Eldorado», «Епіцентр», «Foxtrot», «Comfy» тощо) та іншими службами доставки («UKLON», «Нова пошта» тощо). Для цього спеціалізоване підприємство може заклю- чати договори на надання транспортних послуг як з торгівельними підприємствами, які мають власні служби доставки, так і з підприємствами, що надають такі послуги безпосередньо. Таким чином, оператор руху BEEO, співпрацюючи з місцевими службами доставки, та спеціалізоване переробне підприємство можуть забезпечити: збирання та перевезення електронних відходів від користувача до переробного підприємства; попереднє сортування з подальшим демонтуванням та ідентифікацією частин; оцінка вартості; реалізація вторинної сировини та модулів/ деталей.
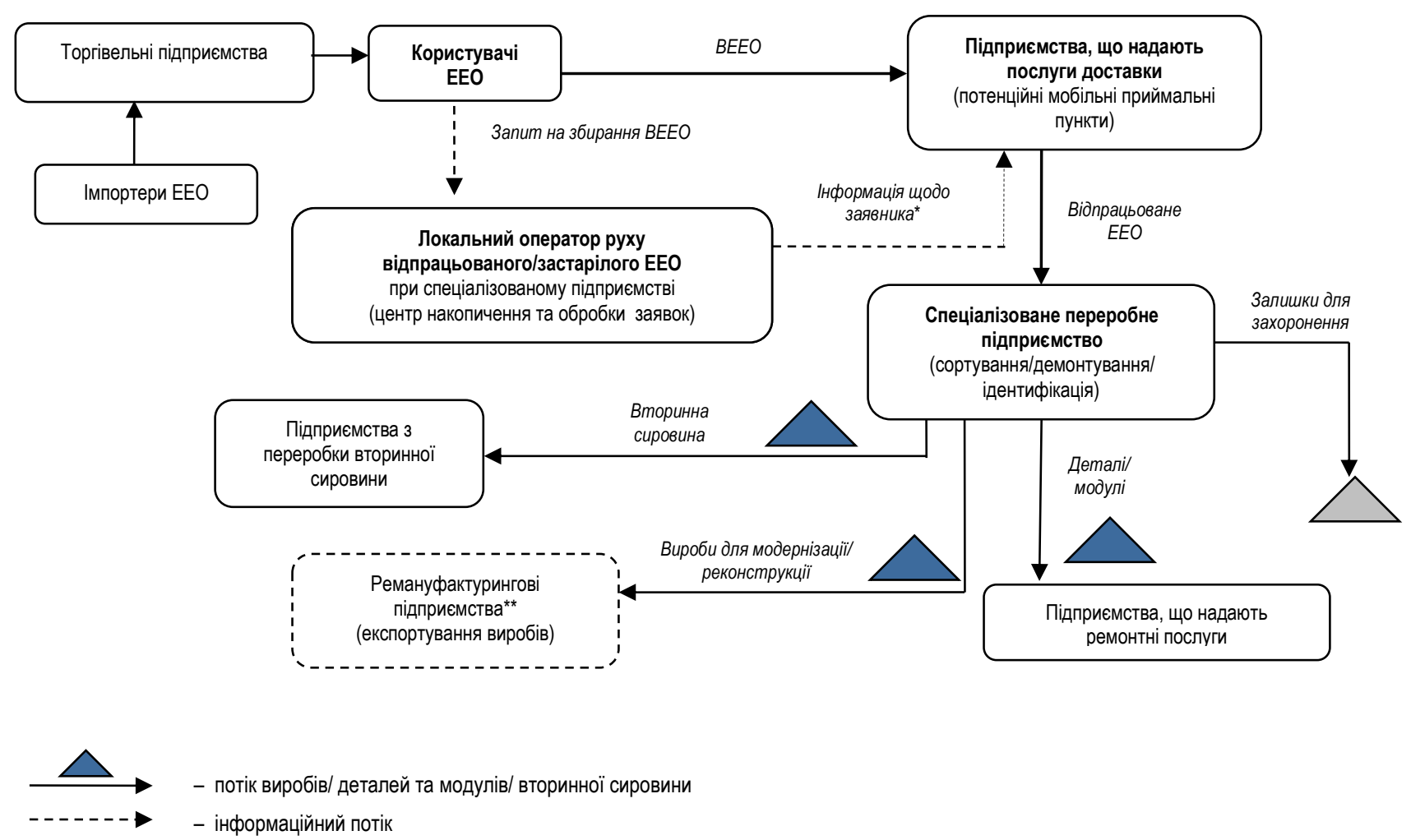

* Оброблений та відображений на інтерактивній карті запит користувача на збирання ВЕEО.

** Закордонні ремануфактурингові підприємства для реалізації виробів та модулів для відновлення.

Рисунок 5 - Схема забезпечення реверсу ВЕEО на основі обробки заявок користувачів на збирання та залучення підприємств, що надають послуги доставки

Джерелом коштів для забезпечення зворотного руху BEEO та подальшого поводження з ними є дохід від реалізації вторинної сировини переробним підприємствам та дохід від реалізації функціонуючих частин старого обладнання ремонтним/ виробничим підприємствам (українським або закордонним).

\section{Висновок}

Обґрунтовано доцільність створення локального оператора руху ВEEO при спеціалізованому переробному підприємстві для запобігання розвитку неформального сектору поводження з цими відходами в Україні. Встановлено, що для якомога повнішого повернення відпрацьованих виробів через офріційні канали збирання слід застосовувати технології мотивації користувачів, які дозволяють компенсувати частину залишкової вартості відпрацьованого/ застарілого виробу.
Результатом наукового дослідження є розробка системи реверсу BEEO, за десятьма категоріями, від користувача до переробного підприємства на основі електронної обробки запитів користувачів на збирання цих відходів та створення відповідної інформаційної бази. Система передбачає залучення транспортних засобів служб доставки міста для збирання цього типу відходів, замість введення цільового транспорту для збирання відходів. Створення інформаційної бази запитів з відповідними інтерактивними online-картами дозволить мінімізувати транспортні витрати та зменшити CO2 за рахунок використання наявного потенціалу маршрутів транспортних засобів служб доставки для роздільного збирання електронних відходів у місті. 


\section{Список використаної літератури:}

1. Андрєєва Н.М., Барун М.В. Використання інноваційно-наукового центру з впровадження ресурсозберігаючих та еколого орієнтованих проектів на базі краудсорсингової платформи. Вісник ОНУ імені І.І. Мечникова. Одеса. 2014. Т.19. Вип. 3/3. C.126-130.

2. Виговська Г.П. Концептуально-методологічні засади мінімізації відходів на базі оцінювання життєвого циклу продуктів та матеріалів. Екологічні науки. 2013. № 4. С. 111-125.

3. Губанова О.Р. Електронні відходи: теорія та практика поводження: Монографія / О.Р. Губанова. - Одеса: «ТЕС», 2014. $-120 \mathrm{c}$.

4. Коджебаш А. П., Хумарова Н. І. Транспортно-логістична система відповідального поводження з відходами: економіко-екологічні чинники та інструменти // Економічний простір. 2019. № 144. С. 194-210.

5. Шевченко Т.І. Електронна карткова система нарахування бонусів як технологія мотивації користувача до участі у сортуванні небезпечних побутових відходів / Т.І. Шевченко, О.М. Курило // Вісник СНАУ. Серія Економіка. - 2017. - № 8 (73).

6. Шевченко Т.І. Служби доставки як спосіб забезпечення зворотного руху електронних відходів // Вісник СНАУ. Серія Економіка. - 2018. - №6.

7. Шуптар Н.Й. Інструментальне забезпечення поводження з відпрацьованими джерелами живлення. Глобальні та національні проблеми економіки. 2016. № 9. С. 577-580.

8. Balde C.P., Forti V., Gray V., Kuehr R., Stegmann P. The Global E-waste Monitor - 2017, United Nations University, International Telecommunication Union \& International Solid Waste Association, Bonn/Geneva/Vienna. 2017. Available online: https://www.itu.int/en/ITU-D/Climate-Change/Documents/GEM\%202017/Global-E-waste\%20Monitor\%202017\%20.pdf.

9. Borthakur A., Govind M. Emerging trends in consumers' E-waste disposal behaviour andawareness: A worldwide overview with special focus on India. Resources, Conservation and Recycling, 2017, 117, 102-113.

10. Colesca S.E., Ciocoiu C.N., Popescu M.L. Determinants of WEEE Recycling Behaviour in Romania: A fuzzy Approach. Int. J. Environ. Res. 2014, 8(2), 353-366.

11. Chi X., Wang M.Y.L., Reuter M.A. E-waste collection channels and household recycling behaviors in Taizhou of China. Journal of Cleaner Production. 2014, 80, 87-95. equipment.

12. Directive No 2012/19/EC of the European Parliament and of the Council of 4 July 2012 on waste electrical and electronic

13. Liu X., Tanaka M., Matsui Y. Generation amount prediction and material flow analysis of electronic waste: Case study in Beijing. Waste Management \& Research, 2006, 24(5), 434-445. Doi:10.1177/0734242X06067449

14. Lu C.Y., Zhang L., Zhong Y.G., Ren W.X., Tobias M. et al. An overview of E-waste management in China. J. Mater. Cycles Waste Manage. 2015, 17(1), 1-12. Doi:10.1007/s10163-014-0256-8.

15. Nduneseokwu C.K., Qu Y., Appolloni A. Factors influencing consumers' intentions to participate in a formal e-waste collection system: A case study of Onitsha, Nigeria. Sustainability, 2017, 9(6), 1-17. Doi:10.3390/su9060881.

16. Nnorom I.C., Ohakwe J., Osibanjo O. Survey of willingness of residents to participate in electronic waste recycling in Nigeria - A case study of mobile phone recycling. J. Clean. Prod. 2009, 17, 1629-1637. Doi:10.1016/j.jclepro.2009.08.009.

17. Ongondo F.O., Williams I.D. Mobile phone collection, reuse and recycling in the UK. Waste Management. 2011, 31, 13071315. Doi:10.1016/j.wasman.2011.01.032.

18. Shevchenko T., Danko Y., Krasnorutskyy O. Management of Waste Electrical and Electronic Products in Compliance with the Circular Economy: What are the Future Challenges for EU Member States? International Journal of Ecology \& Development. 2018, 33(3), 47-55.

19. Shevchenko T., Laitala K., Danko Y. Understanding Consumer E-Waste Recycling Behavior: Introducing a New Economic Incentive to Increase the Collection Rates. Sustainability 2019, 11, 2656.

20. United Nations Environmental Program: Recycling e from E-waste to resources, 2009. http://isp.unu.edu/news/2010/files/UNEP_eW2R_publication.pdf.

21. Yu J.L., Williams E., Ju M.T., Shao C.F. Managing e-waste in China: policies, pilot projects and alternative approaches. Resour. Conserv. Recycl. 2010, 54(11), 991-999. Doi:10.1016/j.resconrec.2010.02.006.

22. Wang F., Huisman J., Stevels A., Balde C. Enhancing e-waste estimates: Improving data quality by multivariate InputOutput Analysis. Waste Management, 2013, 33, 2397-2407.

23. Wang Z., Zhang B., Yin J., Zhang X. Willingness and behavior towards e-waste recycling for residents in Beijing city, China. Journal of Cleaner Production. 2011, 19, 977-984. Doi:10.1016/j.jlepro.2010.09.016.

Shevchenko T., PhD, Associate Professor, Sumy National Agrarian University (Sumy, Ukraine)

Honcharova N., Lecturer, Hlukhiv agrotechnical institute of Sumy National Agrarian University (Hlukhiv, Ukraine)

Melnyk Yu., student, Sumy National Agrarian University (Sumy, Ukraine)

Feasibility of establishing the local operator of e-waste movement from user to processing enterprise for prevention of informal sector of waste management in Ukraine

The article substantiates the feasibility of creating a local operator for collection of waste electrical and electronic equipment to prevent the development of waste management informal sector in Ukraine. We propose an e-waste reverse logistic system, by ten categories, from user to processing enterprise based on the electronic processing of user requests on this waste collection and creation of appropriate information database. A query database with relevant online maps will minimize transport costs and reduce $\mathrm{CO} 2$ due to 
use of vehicles' routes available potential of local delivery services for separate collection of e-waste in the city instead of introducing targeted transport for e-waste collection.

Keywords: municipal solid waste, e-waste, waste electrical and electronic equipment, informal sector, e-waste collection, recycling.

Дата надходження до редакції: 27.07.2019 р. 